Kampus 4 Universitas Ahmad Dahlan Jl. Ringroad Selatan, Tamanan, Banguntapan, Bantul

Daerah Istimewa Yogyakarta 55191

Telp. : (0274) 563515 Fax. : (0274) 564604

e-mail : ihtifaz@uad.ac.id

Vol.1, No 1\&2, Juni-Desember 2018, pp. 123-136

ISSN p:2622-4755 e:2622-4798.

DOI: https://doi.org/10.12928/ijiefb.v1i1.286

\title{
Deteksi Kebangkrutan pada Industri Asuransi Syariah di Indonesia
}

\author{
Fayakhun Bakhtiar ${ }^{1 *}$, Misbahul Munir ${ }^{1}$, Ahsan Al Qasas ${ }^{1}$ \\ ${ }^{1}$ Magister Ekonomi dan Keuangan, Universitas Islam Indonesia, \\ Sleman, Indonesia \\ *e-mail: 17918001@students.uii.ac.id
}




\title{
Deteksi Kebangkrutan pada Industri Asuransi Syariah di Indonesia
}

\author{
Fayakhun Bakhtiar ${ }^{1 *}$, Misbahul Munir ${ }^{1}$, Ahsan Al Qasas ${ }^{1}$ \\ ${ }^{1}$ Magister Ekonomi dan Keuangan, Universitas Islam Indonesia, \\ Sleman, Indonesia \\ *e-mail: 17918001@students.uii.ac.id
}

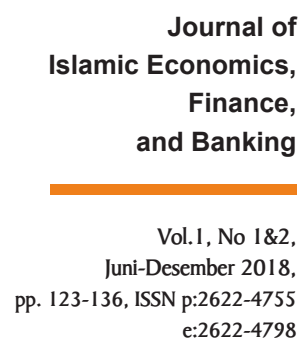

\begin{abstract}
This study aims to predict the potential bankruptcy of a sharia insurance company. The analysis model used is the modified Altman Z-score analysis model. The Altman Z-score measurement model will be represented by the ratio of the network model to total assets, retained earnings to total assets, earnings before interest to total assets and capital book value to the book value of debt. The results showed that from 2011 to 2017 in 5 sharia insurance companies were in a safe zone (not bankrupt), there was only one sharia insurance company in the gray zone.
\end{abstract}

\section{Keywords:}

Sharia Insurance, Altman Z-score, Bankruptcy

\begin{abstract}
Abstrak
Penelitian ini bertujuan untuk memprediksi potensi kebangkrutan dari perusahaan asuransi syariah. Model analisis yang digunakan adalah model analisis Altman Z-score modifikasi. Model Altman Z-score pengukurannya akan diwakilkan oleh rasio model kerja bersih terhadap total aset, laba ditahan terhadap total aset, laba sebelum bunga terhadap total aset dan nilai buku modal terhadap nilai buku hutang. Hasil penelitian menunjukkan selama tahun 2011 hingga 2017 pada lima perusahaan asuransi syariah berada pada keadaan safe zone (tidak bangkrut), hanya ada 1 perusahaan asuransi syariah yang berada pada keadaan grey zone.
\end{abstract}

\section{Kata Kunci:}

Asuransi Syariah, Altman Z-score, Kebangkrutan

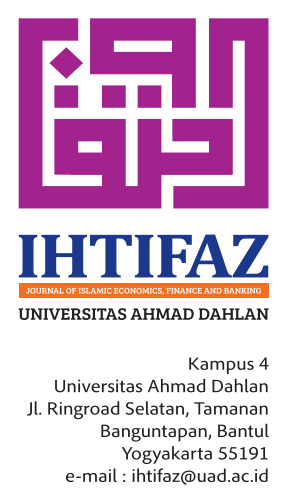




\section{PENDAHULUAN}

Perkembangan industri dan dunia usaha di berbagai sektor IHTIFAZ - JIEFB berdampak pada pertumbuhan ekonomi yang terus meningkat. Namun terkadang peningkatan pertumbuhan industri dan dunia usaha tersebut diliputi oleh rasa khawatir akibat ketidakpastian kondisi ekonomi, baik kondisi ekonomi regional maupun ekonomi global. Ketidakpastian tersebut menimbulkan risiko yang harus dihadapi oleh semua pelaku usaha. Risiko memang tidak bisa dihindari, namun setidaknya bisa diatur atau diminimalisir. Asuransi adalah salah satu cara yang bisa diambil guna meminimalisir risiko.

Asuransi terbagi menjadi dua, yaitu asuransi jiwa dan asuransi umum. Asuransi jiwa sebagaimana yang telah diketahui pada umumnya, yaitu memberikan jaminan kesehatan. Apabila nasabah sakit, maka pihak asuransi akan menanggung biaya berobat nasabah. Sedangkan asuransi umum, pada umumnya yang diasuransikan adalah barangbarang yang memiliki nilai materi seperti harta kekayaan, rumah, kendaraan dan lain sebagainya (Adnan dan Taufik, 2001).

Perkembangan asuransi di Indonesia terus mengalami peningkatan yang cukup baik, walaupun masih di bawah negara-negara maju (Altman, 1968). Pengertian asuransi dijelaskan dalam undang-undang nomor 2 tahun 1992, yang dimaksud dengan asuransi adalah "perjanjian antara dua belah pihak atau lebih, yang mana pihak penanggung mengikatkan diri kepada pihak tertanggung, dengan menerima presi asuransi, untuk memberikan penggangti kepada tertanggung karena kerugian, kerusakan atau kehilangan keuntungan yang tidak diharapkan, atau tanggung jawab hukum kepada pihak ketiga yang kemungkinan akan diderita oleh pihak tertanggung, yang timbul dari suatu peristiwa yang tidak pasti, atau untuk memberikan suatu pembayaran yang didasarkan atas meninggal atau hidupnya seseorang yang dipertanggungkan" (DSN-MUI, 2001). Adanya asuransi bertujuan untuk menjamin berbagai kemungkinan kerugian yang akan dihadapi oleh pihak tertanggung karena adanya ketidakpastia risiko sehingga posisi tertanggung akan terhindar dari risiko akan kerugian atau hal-hal yang tidak diinginkan (Adnan dan Taufik, 2001).

Dalam perkembangannya, pengelolaan asuransi terbagi menjadi dua, yaitu asuransi yang dikelola secara konvensional dan asuransi yang dikelola berdasarkan prinsip-prinsip syariah (asuransi syariah). Asuransi konvensional sederhananya dapat dipahami sebagai pengalihan risiko dari pihak tertanggung kepada pihak penanggung. Sedangkan asuransi syariah dapat dipahami sebagai pengalihan risiko yang dikelola berdasarkan prinsip-prinsip syariah, di mana salah satu prinsipnya adalah untuk saling tolong menolong (tabarru').

Asuransi syariah dalam penjelasan berdasarkan fatwa Dewan Syariah Nasional Majelis Ulama Indonesia (DSN MUI) No. 21/DSN/-MUI/X/2001 diartikan sebagai "usaha untuk saling melindungi atau tolong menolong 
di antara sejumlah orang atau pihak melalui investasi dalam bentuk aset dan atau tabarru' (tolong menolong) yang memberikan pola pengembalian untuk menghadapi risiko tertentu melalui akad (perikatan) yang sesuai dengan prinsip-prinsip syariah".

Perkembangan asuransi syariah di Indonesia dimulai pada tahun 1994 yaitu saat mulai berdirinya Asuransi Takaful Indonesia yang diprakarsai oleh Tim Pembentuk Asuransi Takaful Indonesia (TIPATI) dan dipelopori oleh Ikatan Cendikia Muslim Indonesia (ICMI) melalui

Journal of Islamic Economics, Finance, and Banking

Vol. 1, No 1\&2, Juni-Desember 2018, pp. 123-136, ISSN p:2622-4755 e:2622-4798 Yayasan Abdi Bangsa, Bank Muamalat Indonesia, Asuransi Jiwa Tugu Mandiri, pejabar dari Departemen Keuangan, dan Pengusaha Muslim Indonesia. Dalam perkembangannya, pertumbuhan asuransi syariah di Indonesia masih berada di bawah pertumbuhan asuransi konvensional (Mutawali, 2016).

Grafik 1. Data Keuangan Asuransi Syariah Mei 2017-Mei 2018

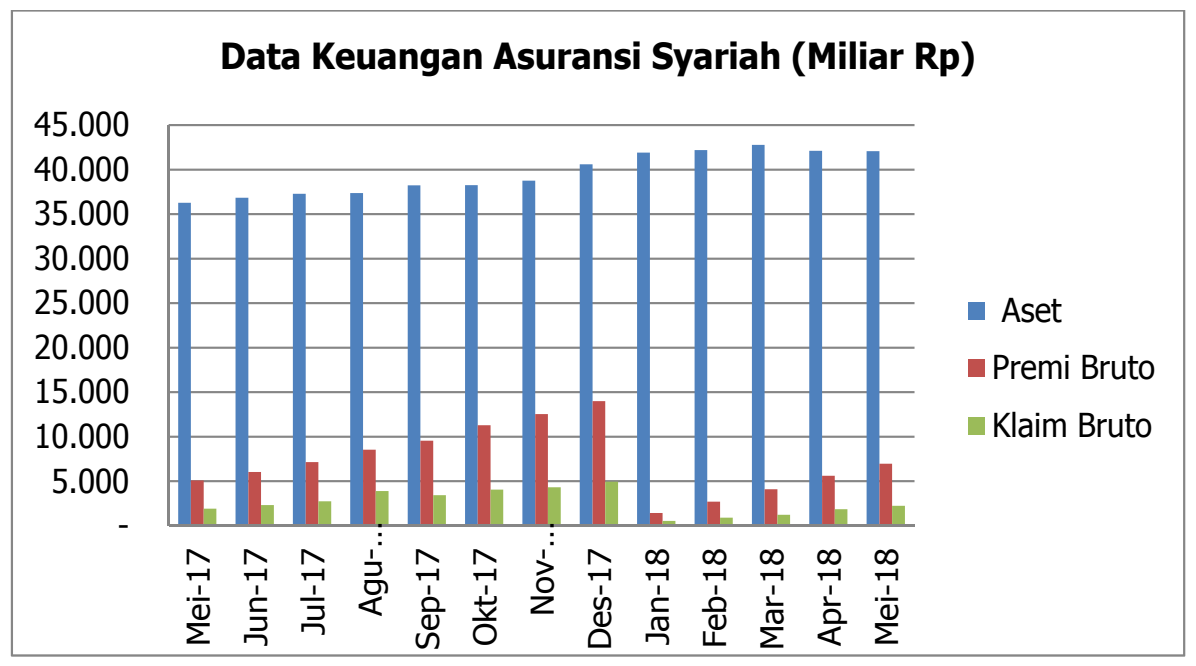

Sumber: (OJK, 2018)

Perkembangan terkini, berdasarkan data laporan statistik bulanan Industri Keuangan Non Bank (IKNB) SyariahOtoritas Jasa Keuangan (OJK), mengenai data keuangan asuransi syariah. Pada Mei 2018 total aset asuransi syariah mencapai angka 46,06 triliun, meningkat dari periode yang sama tahun 2017 sebesar 36,27 triliun. Sedangkan untuk total premi asuransi syariah pada Mei 2018 mencapai angka 6,35 triliun, meningkat jika dibandingkan dengan periode yang sama tahun sebelumnya sebesar 5,08 triliun. Kemudian untuk total klaim, pada Mei 2018 sebesar 2,24 triliun, angka ini meningkat dari periode sebelumnya Mei 2017 sebesar 1,91 triliun (OJK, 2018).

Sebagai lembaga keuangan non bank, asuransi syariah juga berpotensi mengalami kerugian atau kebangkrutan. Berdasarkan peraturan Otoritas Jasa Keuangan nomor 1/POJK.05/2015 tentang Penerapan Manajemen Risiko Bagi Lembaga Jasa Keuangan Non-Bank, 
perlu untuk menerapkan fungsi identifikasi, pengukuran, pamantauan, dan pengendalian risiko yang memadai. Hal ini dilakukan agar lembaga jasa keuangan non bank dalam menjalankan usahanya patuh terhadap aturan dan agar tidak ada pihak yang dirugikan. Maka, asuransi syariah sebagai lembaga keuangan non bank juga harus tunduk dan patuh dengan peraturan tersebut (OJK, 2015).

\section{METODE}

Model analisis yang digunakan adalah Multiple Discriminant Analysis (MDA) atau yang lebih dikenal dengan nama Altman Z-score. Dalam penelitian ini model Altman Z-score yang digunakan adalah model Altman Z-score modifikasi. Model Altman Z-score modifikasi ini dapat digunakan pada semua perusahaan seperti manufaktur, non manufaktur, dan perusahaan penerbit obligasi di negara berkembang/ emerging market (Fatmawati, 2016).

Sistem peringatan dini (early warning system) untuk memprediksi adanya keadaan kesulitan keuangan (financial distress) yang menuju kearah kebangkrutan. Ada beberapa model analisis yang dapat digunakan untuk memprediksi potensi kebangkrutan perusahaan, salah satunya adalah dengan model Altman Z-Score (Adnan dan Taufik, 2001). Model analisis ini dikemukakan oleh Edward I. Altman pada tahun 1968. Model analisis ini menggunakan rasio-rasio tertentu sebagai model prediksi dengan menggunakan teknik Mutliple Discriminant Analysis (MDA). Rasio yang digunakan mecerminkan rasio likuiditas, profitabilitas, leverage dan aktivitas perusahaan. Dengan adanya kombinasi dari rasiorasio tersebut, maka model analisis ini akan sangat membantu untuk mengetahui kinerja keuangan perusahaan dan dapat membantu juga dalam memprediksi potensi kebangkrutan yang mungkin dialami oleh sebuah perusahaan (Ramdhani dan Lukviarman, 2009).

Dalam analisis Altman Z-score modifikasi ini mengeliminasi variabel X5 (sales to total assets), karena perusahaan non manufaktur tidak mempunyai akun sales (penjualan) dan mengganti X4 (market value of equity to book value of debt) menjadi book value of equity to book value of debt (nilai buku ekuitas terhadap total kewajiban), dikarenakan banyak industri yang belum listing di bursa saham sehingga belum mempunyai nilai pasar saham (Redhika dan Mahalli, 2014).

Rasio ini sangat bervariatif pada industri dengan ukuran aset yang berbeda-beda. Maka, formula persamaan z-score yang telah dimodifikasi oleh Edward I. Altman menunjukkan fungsi diskriminan sebagai berikut:

\section{$Z=6.56 X \_1+3.26 X \_2+6.72 X \_3+1.05 \times \_4$}

Dimana:

X_1=Net Working Capital to Total Assets

X_2=Retained Earning to Total Assets 
X_3=Earning Before Tax to Total Assets

$X \_4=$ Book Value of Equity to Book Value of Debt

$\mathrm{Z}=$ Overall Index

Klasifikasi perusahaan yang bangkrut, grey area dan tidak bangkrut didasarkan pada nilai z-score modifikasi adalah:

Nilai $Z<1,23$ dikategorikan perusahaan bangkrut.

Vol.1, No 1\&2, Juni-Desember 2018 , pp. 123-136, ISSN p:2622-4755 e:2622-4798

Nilai $1,23<Z<2,90$ dikategorikan dalam grey area, perusahaan tersebut tidak dapat dikatakan bangkrut tapi juga tidak dapat dikatakan sehat.

Nilai Z $\geq 2,90$ dikategorikan perusahaan tidak bangkrut.

\section{HASIL DAN PEMBAHASAN}

Penelitian ini bertujuan untuk melakukan uji potensi kebangkrutan industri asuransi syariah di Indonesia dengan modal Altman Z-Score periode data tahun 2011 sampai 2017.Penilaian dilakukan dengan menggunakan model Altman Z-score modifikasi, yaitu suatu model menggunakan analisis diskriminan alternatif yang dikembangkan oleh Altman dan untuk perhitungannya menggunakan empat rasio keuangan yang menjadi variabel. Untuk menentukan nilai Z dan mengkategorikan nilai tersebut kedalam kelompok yang telah ditentukan makayang dilakukan adalah menghitung rasio keuangan yang ada dalam model Altaman Z-score modifikasi. Rasio tersebut adalah:

$$
\text { X_1=Net Working Capital to Total Assets }
$$

Berdasarkan perhitungan menggunakan rasio net working capital to total assets (modal kerja bersih terhadap total aktiva). Rumus yang digunakan:

Net Working Capital to Total Asset = (Aset Lancar-Kewajiban Lancar)/(Total Aktiva)

Penggunaan rumus tersebut dimaksudkan untuk menghasilkan nilai rasio net working capital to total assets untuk perusahaan asuransi syariah dari tahun 2011-2017.

Tabel 1. Perhitungan Net Working Capital to Total Assets (X1)

\begin{tabular}{lccccccc}
\hline \multirow{2}{*}{ Nama Perusahaan } & \multicolumn{7}{c}{ Net Working Capitall to Total Asset (X1) } \\
& 2011 & 2012 & 2013 & 2014 & 2015 & 2016 & 2017 \\
PANINDAI - ICHILIFE & 0.47 & 0.46 & 0.36 & 0.52 & 0.45 & 0.51 & 0.36 \\
\hline MEGA SYARIAH & 0.83 & 0.47 & 0.44 & 0.52 & 0.54 & 0.59 & 0.80 \\
TAKAFUL KELUARGA & 0.17 & 0.15 & 0.15 & 0.15 & 0.15 & 0.12 & 0.22 \\
PRUDENTIAL SYARIAH & 0.40 & 0.65 & 0.69 & 0.71 & 0.71 & 0.03 & 0.82 \\
SINARMAS SYARIAH & 0.57 & 0.51 & 0.02 & 0.02 & 0.03 & 0.02 & 0.46 \\
ADIRA SYARIAH & 0.57 & 0.51 & 0.02 & 0.06 & 0.35 & 0.10 & 0.50 \\
Sumber: Data Diolah (2018). & & & & & & \\
\hline \hline
\end{tabular}

Ihtifaz: Journal of Islamic Economics, Finance, and Banking 
Data pada tabel 1 mendiskripsikan bahwa rasio net working capital to total assets perusahaan asuransi syariah dalam kurun waktu 7 tahun terakhir menunjukkan nilai yang bervariatif. Bila ditinjau dari rasio yang dihasilkan, pada tahun 2011 perusahaan asuransi Mega Syariah meghasilkan rasio sebesar 0.83 , artinya setiap pemakaian Rp 1,- aktiva yang dimiliki perusahaan asuransi Mega Syariah mampu mengasilkan modal kerja bersih sebesar Rp 0,83. Di tahun 2012 Prudential Syariah mampu mendapatkan rasio net working capital to total asset 0,62. Semakin tinggi rasio yang dihasilkan menunjukkan perusahaan asuransi syariah semakin baik menghasikan modal kerja bersih, tentunya hal ini berakibat pada semakin tinggi tingkat likuiditas perusahaan asuransi syariah tersebut. Rasio terendah ditahun 2017 dihasilkan perusahaan asuransi syariah Takaful Keluarga dengan nilai rasio 0,22. Rasio ini diartikan setiap pemakaian $\mathrm{Rp} \mathrm{1,-} \mathrm{aktiva} \mathrm{bersih}$ hanya mampu mengahasilkan modal kerja bersih sebesar Rp 0,22,- . Hal ini berbeda dengan rasio yang berhasil dicapai oleh perusahaan asuransi syariah Prudential Syariah. Pada tahun 2017, Pudential Syariah berhasil mendapatkan rasio net working capital sebesar 0,82. Artinya setiap pengguanaan Rp 1,- aktiva, mampu menghasilkan modal kerja bersih sebesar Rp 0,82,-.

\section{X_2 = Retained Earning to Total Assets}

Menghitung rasio retained earning to total assets (laba ditahan terhadap aktiva) menggunakan rumus:

Retained Earning to Total Assets $=($ Laba Ditahan $) /($ total Aktiva $)$

Dengan menggunakan rumus tersebut menghasilkan nilai rasio retained earnings to total assets (laba ditahan terhadap aktiva)untuk perusahaan asuransi syariah dari tahun 2011 hingga 2017.

Tabel 2. Perhitungan Retained Earning to Total Assets (X2)

\begin{tabular}{lccccccc}
\hline \multirow{2}{*}{ Nama Perusahaan } & \multicolumn{7}{c}{ Retained Earning to Total Asset (X2) } \\
& 2011 & 2012 & 2013 & 2014 & 2015 & 2016 & 2017 \\
& & & & & & & \\
PANINDAI - ICHILIFE & 0.13 & 0.20 & 0.20 & 0.29 & 0.28 & 0.35 & 0.39 \\
MEGA SYARIAH & 0.07 & 0.16 & 0.22 & 0.34 & 0.38 & 0.44 & 0.52 \\
TAKAFUL KELUARGA & $(0.04)$ & $(0.03)$ & $(0.01)$ & 0.01 & 0.03 & 0.03 & 0.01 \\
PRUDENTIAL SYARIAH & 0.39 & 0.65 & 0.68 & 0.70 & 0.71 & 0.03 & 0.25 \\
SINARMAS SYARIAH & 0.25 & 0.30 & 0.38 & 0.35 & 0.43 & 0.54 & 0.52 \\
ADIRA SYARIAH & 0.25 & 0.30 & 0.27 & 0.29 & 0.30 & 0.26 & 0.24 \\
\hline Sumber: Data Diolah (2018) & & & & & & &
\end{tabular}


Data tabel 2 memperlihatkan bahwa perkembangan nilai rasio ini selama kurun waktu 7 tahun terakhir pada setiap perusahaan asuransi syariah menunjukkan nilai yang cukup bervariatif. Asuransi Takaful Keluarga dari tahun 2011 hingga 2013 menunjukkan nilai rasio retained earning to total asset negatif. Hasil rasio ini memungkinkan bernilai negatif dikarenakan nila dari laba ditahan yang dimiliki perusahaan

Journal of Islamic Economics, Finance, and Banking

Vol.1, No 1\&2, Juni-Desember 2018, asuransi syariah tersebut juga minus. Semakin tinggi rasio retained pp. 123-136, ISSN p:2622-4755 earning to total assets ini menunjukkan indikasi laba ditahan yang dihasilkan perusahaan asuransi syariah semakin tinggi. Di tahun 2013 rasio retained earning to total asset tertinggi dimiliki oleh perusahaan asuransi Prudential Syariah sebesar 0,68. Arti dari nilai ini adalah setiap penggunaan Rp 1,- aktiva oleh perusahaan asuransi Prudential Syariah akan menghasilkan laba ditahan sebesar Rp 0,38.

\section{X_3=Earning Before Tax to Total Assets}

Cara menghitung rasio earning before tax to total assets (laba sebelum pajak terhadap total aktiva) menggunakan rumus: Aktiva)

Earning Before Tax to Total Assets $=($ Laba Sebelum Pajak $) /($ Total

Penggunaan rumus tersebut dimaksudkan untuk menghasilkan rasio earning before tax to total assets untuk perusahaan asuransi syariah tahun 2011 hingga 2017.

Tabel 3. Perhitungan Earning Before Tax to Total Assets (X3)

\begin{tabular}{|c|c|c|c|c|c|c|c|}
\hline \multirow{2}{*}{ Nama Perusahaan } & \multicolumn{7}{|c|}{ Earning Before Tax to Total Assets (X3) } \\
\hline & 2011 & 2012 & 2013 & 2014 & 2015 & 2016 & 2017 \\
\hline PANINDAI - ICHILIFE & 0.05 & 0.10 & 0.05 & 0.10 & 0.07 & 0.08 & 0.08 \\
\hline MEGA SYARIAH & 0.03 & 0.12 & 0.11 & 0.16 & 0.09 & 0.07 & 0.05 \\
\hline TAKAFUL KELUARGA & 0.02 & 0.01 & 0.02 & 0.02 & 0.02 & 0.01 & 0.01 \\
\hline PRUDENTIAL SYARIAH & 0.86 & 0.72 & 0.57 & 0.54 & 0.44 & 0.01 & 0.09 \\
\hline SINARMAS SYARIAH & 0.14 & 0.14 & 0.18 & 0.17 & 0.17 & 0.18 & 0.10 \\
\hline ADIRA SYARIAH & 0.14 & 0.14 & 0.11 & 0.09 & 0.07 & 0.06 & 0.03 \\
\hline
\end{tabular}

Sumber: Data Diolah (2018)

Data pada tabel 3 menunjukkan pada tahun 2011 - 2015 rasio earning before tax to total assets tertinggi dimiliki oleh prudential syariah dengan rasio sebesar 0,$86 ; 0,72 ; 0,57 ; 0,54$ dan 044 . Artinya di tahun 2011 setiap penggunaan Rp 1,- aktiva yang dimiliki Prudential Syariah mampu menghasilkan laba sebelum pajak sebesar Rp 0,86. Namun, pada tahun 2016 dan 2017 Prudential Syariah mengalami penurunan rasio, menjadi 0,01 dan 0,09. Hal ini dimungkinkan saja 
terjadi, dikarenakan adanya penurunan nilai laba sebelum pajak yang dibukukan. Bila ditinjau dari laporan keuangan yang disajikan oleh

perusahaan asuransi Prudential Syariah, ada peningkatan biaya yang cukup signifikan dari tahun 2015 ke tahun 2016. Ditahun 2015, biaya yang dibukukan Pudential Syariah sebesar Rp 647,7 miliar sedangkan ditahun 2016 biaya yang dibukukan sebesar Rp 869 miliar. Terjadi peningkatan biaya sekitar $34,17 \%$, hal ini semakin memberikan dampak yang signifikan bila ditinjau dari capaian pendapatan ditahun 2015 dan 2016. Pendapatan yang berhasil dibukukan ditahun 2015 sebesar 1,962 triliun, namun di tahun 2016 pendapatan yang berhasil dibukukan sebesar 1,890 triliun. Terjadi penurunan pendapatan sebesar 3,7\%. Rasio tertinggi earning before tax to total asset di tahun 216 dimiliki oleh perusahaan asuransi Sinarmas Syariah dengan raihan rasio sebesar 0,18. Rasio earning before tax to total asset perusahaan asuransi Sinarmas Syariah memiliki rasio yang stabil dari tahun 2011 hingga 2017.

\section{X_4= Book Value of Equity to Book Value of Total Debts}

Untuk menghitung rasio book value of equity to book value of total debts menggunakan rumus :

Book Value of Equity to Book Value of Debt = (Nilai Buku Ekuitas)/ (Total Kewajiban)

Penggunaan rumus tersebut dimaksudkan untuk meghitung nilai rasio book value of equity to book value of debt perusahaan asuransi syariah dari tahun 2011 sampai dengan 2017.

Tabel 4. Perhitungan Book Value of Equity to Book Value of Debt (X4)

\begin{tabular}{lccccccc}
\hline \multirow{2}{*}{ Nama Perusahaan } & \multicolumn{9}{c}{ Book Value of Equity to Book Value of Debt (X4) } \\
& 2011 & 2012 & 2013 & 2014 & 2015 & 2016 & 2017 \\
\hline PANINDAI - ICHILIFE & 8.11 & 3.50 & 1.30 & 1.41 & 0.98 & 11.28 & 8.44 \\
MEGA SYARIAH & 1.74 & 0.94 & 0.84 & 1.23 & 1.39 & 1.85 & 3.33 \\
TAKAFUL KELUARGA & 0.20 & 0.18 & 0.18 & 0.18 & 0.18 & 0.13 & 0.11 \\
PRUDENTIAL SYARIAH & 0.85 & 2.92 & 3.41 & 4.44 & 4.79 & 5.70 & 4.66 \\
SINARMAS SYARIAH & 1.35 & 1.08 & 1.16 & 0.97 & 1.18 & 1.81 & 1.43 \\
ADIRA SYARIAH & 1.35 & 1.08 & 0.54 & 0.60 & 0.62 & 0.49 & 0.40 \\
\hline
\end{tabular}

Sumber: Data Diolah (2018)

Tabel 4 menunjukkan bahwa data rasio book value of equity to book value of debt perusahaan asuransi syariah dari tahun 2011 sampai dengan 2017. Perusahaan asuransi Takaful Keluarga dari tahun 2011 sampai dengan 2017 menghasilkan rasio terendah bila dibandingkan dengan perusahaan asuransi lainnya. Pada tahun 2017, perusahaan asuransi Takaful Keluarga menghasilkan rasio terendah bila dibandingkan dengan pencapaian tahun-tahun sebelumnya, sebesar 0,11. Pada tahun 
tersebut Takaful Keluarga memiliki total kewajiban sebesar Rp 1,490 triiliun, sedangkan nilai buku ekuitas yang dibukukan ditahun yang sama sebesar Rp 170,120 miliar. Artinya setiap Rp 1,- total kewajiban yang dimiliki oleh perusahaan asuransi Takaful Keluarga hanya bisa dicakup oleh nilai buku ekutias sebesar Rp 0,11. Pada tahun 2017, rasio tertinggi berhasil dicapai oleh perusahaan asuransi Panindai-Ichilife dengan rasio

sebesar 8,44. Hal ini artinya setiap Rp 1,- total kewajiban yang dimiliki perusahaan asuransi syariah Panindai-Ichilife mampu dicakup sebesar Rp 8,44 oleh nilai buku ekuitas yang dimiliki perusahaan tersebut.

\section{HASIL ALTMAN Z-SCORE}

Berdasarkan data dari perhitungan keempat variabel yang digunakan dalam model Altman Z-Score modifikasi diatas, maka selanjutnya memasukan hasil tersebut kedalam model persamaan Altman Z-score modifikasi dengan mengkalikan hasil data diatas dengan nilai konstanta atau standar dari masing-masing variabel. Model persamaan dan hasil dari perhitungan berdasarkan Alman Z-Score modifikasi adalah:

$$
Z=6,56 \text { X_1+3,26 X_2+6,72 X_3+1,05 X_4 }
$$

Hasil analisis model Altman Z-Score modifikasi tahun 2011, setelah dimasukkan ke dalam persamaan di atas adalah:

Tabel 5. Perhitungan Z-Score tahun 2011

\begin{tabular}{lcrccc}
\hline \multicolumn{1}{c}{ Tahun 2011 } & $\mathbf{X 1}$ & $\mathbf{X 2}$ & $\mathbf{X 3}$ & $\mathbf{X 4}$ & \multirow{2}{*}{ Z Score } \\
& $\mathbf{6 . 5 6}$ & $\mathbf{3 . 2 6}$ & $\mathbf{6 . 7 2}$ & $\mathbf{1 . 0 5}$ & \\
\hline PANINDAI - ICHILIFE & 3.069043 & 0.426723 & 0.308122 & 8.520729 & 12.32462 \\
MEGA SYARIAH & 5.428233 & 0.231691 & 0.223584 & 1.827457 & 7.710964 \\
TAKAFUL KELUARGA & 1.093771 & -0.1233 & 0.114673 & 0.210142 & 1.295282 \\
PRUDENTIAL SYARIAH & 2.612205 & 1.276633 & 5.755145 & 0.888061 & 10.53204 \\
SINARMAS SYARIAH & 3.742514 & 0.808302 & 0.939612 & 1.418467 & 6.908895 \\
ADIRA SYARIAH & 3.746746 & 0.808302 & 0.939612 & 1.418467 & 6.913127 \\
\hline
\end{tabular}

Sumber: Data Diolah (2018)

Tabel 5 menunjukkan hasil perhitungan, nilai Z-Score dari keseluruhan perusahaan asuransi syariah pada tahun 2011. Perusahaan asuransi syariah Takaful Keluarga pada tahun 2011 medapatkan nilai Z-score sebesar 1,29. Berdasarkan hasil tersebut, perusahaan asuransi Takaful Keluarga di tahun 2011 dikategorikan dalam grey area, karena nilai Z-score yang dihasilkan berada di rentang $1,23<Z<2,90$, artinya perusahaan asuransi Takaful Keluarga tidak dapat dikatakan bangkrut, tetapi juga tidak dapat dikatakan sehat. 
Tabel 6. Perhitungan Z-Score tahun 2012

\begin{tabular}{llccccc}
\cline { 2 - 7 } IHTIFAZ - JIEFB & \multirow{2}{*}{ TAHUN $\mathbf{2 0 1 2}$} & $\mathbf{X 1}$ & $\mathbf{X 2}$ & $\mathbf{X 3}$ & $\mathbf{X 4}$ & \multirow{2}{*}{ S Score } \\
\cline { 2 - 7 } & & $\mathbf{6 . 5 6}$ & $\mathbf{3 . 2 6}$ & $\mathbf{6 . 7 2}$ & $\mathbf{1 . 0 5}$ & \\
\cline { 2 - 7 } & PANINDAI - ICHILIFE & 3.017345 & 0.643503 & 0.673694 & 3.674959 & 8.009501 \\
& MEGA SYARIAH & 3.085212 & 0.522761 & 0.806903 & 0.988232 & 5.403108 \\
& TAKAFUL KELUARGA & 0.984624 & -0.08225 & 0.048085 & 0.185432 & 1.135892 \\
& PRUDENTIAL SYARIAH & 4.263564 & 2.102782 & 4.853893 & 3.070113 & 14.29035 \\
& SINARMAS SYARIAH & 3.333912 & 0.982619 & 0.942164 & 1.131237 & 6.389932 \\
& ADIRA SYARIAH & 3.333912 & 0.982619 & 0.942164 & 1.131237 & 6.389932 \\
\hline
\end{tabular}

Sumber: Data Diolah (2018)

Nilai Z-score ditahun 2012 bedasarkan perhitungan tabel 6, perusahaan asuransi syariah Takaful Keluarga memiliki nilai Z-score 1,13. Bedasarkan hasil tersebut, perusahaan asuransi Takaful Keluarga ditahun 2012 dikatergorikan perusahaan bangkrut, karena nilai Z-score yang dihasilkan berada dibawah 1,23. $Z<1,23$.

Tabel 7. Perhitungan Z-Score tahun 2013

\begin{tabular}{lrrrrr}
\hline \multicolumn{1}{c}{ TAHUN 2013 } & \multicolumn{1}{c}{$\mathbf{X 1}$} & \multicolumn{1}{c}{$\mathbf{X 2}$} & \multicolumn{1}{c}{$\mathbf{X 3}$} & \multicolumn{1}{c}{$\mathbf{X 4}$} & \multirow{2}{*}{ Score } \\
& $\mathbf{6 . 5 6}$ & \multicolumn{1}{c}{$\mathbf{3 . 2 6}$} & \multicolumn{6}{c}{$\mathbf{6 . 7 2}$} & \multicolumn{1}{c}{$\mathbf{1 . 0 5}$} & \\
\hline PANINDAI - ICHILIFE & 2.334499 & 0.658804 & 0.3479 & 1.367595 & 4.708798 \\
MEGA SYARIAH & 2.864622 & 0.713734 & 0.718917 & 0.879303 & 5.176576 \\
TAKAFUL KELUARGA & 0.993034 & -0.0271 & 0.129493 & 0.187299 & 1.282727 \\
PRUDENTIAL SYARIAH & 4.497385 & 2.224883 & 3.853227 & 3.575714 & 14.15121 \\
SINARMAS SYARIAH & 0.118621 & 1.25435 & 1.238777 & 1.21562 & 3.827367 \\
ADIRA SYARIAH & 0.14804 & 0.874042 & 0.718485 & 0.571737 & 2.312304 \\
\hline
\end{tabular}

Sumber: Data Diolah (2018)

Perusahaan asuransi Adira Syariah di tahun 2013, berdasarkan tabel 7, mengalami penurunan nilai Z-score bila dibandingkankan nilai Z-score ditahun 2011 dan 2012. Faktor terbesar yang mempengaruhi turunya Z-score adalah turunnya rasio net working capital to total assets dan rasio book value of equity to book value of total debt. Meskipun demikian, Adira Syariah tetap berada pada katergori perusahaan tidak bangkrut, karena nilai Z > 2,90. Di tahun 2013, Adira Syariah mendapatkan nilai Z-score sebesar 2,31. Sedangkan perusahaan asuransi syariah Takaful Keluarga di tahun 2013 berhasil memperbaiki kinerjanya dibandingkan tahun sebelumnya. Bila ditahun 2012 perusahaan asuransi syariah Takaful Keluarga berada dalam kategori perusahaan bangkrut, namun di 2013 berada di kategori grey area, perusahaan tersebut tidak dapat dikatakan bangkrut tapi juga tidak dapat dikatergorikan sehat. Karena $Z$-score $(1,28)$ yang dihasilkan berada pada rentang $1,23<Z<2,90$. 
Tabel 8. Perhitungan Z-Score tahun 2014

\begin{tabular}{|c|c|c|c|c|c|c|}
\hline Tahun 2014 & $\begin{array}{c}\text { X1 } \\
6.56\end{array}$ & $\begin{array}{c}\text { X2 } \\
3.26\end{array}$ & $\begin{array}{c}\text { X3 } \\
6.72\end{array}$ & $\begin{array}{c}\text { X4 } \\
1.05\end{array}$ & Z Score & $\begin{array}{r}\text { Islamic Economics, } \\
\text { Finance, } \\
\text { and Banking }\end{array}$ \\
\hline PANINDAI - ICHILIFE & 3.42269 & 0.955276 & 0.667862 & 1.477508 & 6.523336 & \\
\hline MEGA SYARIAH & 3.435758 & 1.11345 & 1.064202 & 1.295038 & 6.908449 & $\begin{array}{r}\text { Vol.1, No } 1 \& 2, \\
\text { Juni-Desember } 2018,\end{array}$ \\
\hline TAKAFUL KELUARGA & 1.007023 & 0.021818 & 0.105255 & 0.185816 & 1.319912 & pp. 123-136, ISSN p:2622-4755 \\
\hline PRUDENTIAL SYARIAH & 4.626538 & 2.29161 & 3.637056 & 4.664659 & 15.21986 & e:2622-4798 \\
\hline SINARMAS SYARIAH & 0.152903 & 1.146863 & 1.121971 & 1.018139 & 3.439876 & \\
\hline ADIRA SYARIAH & 0.376792 & 0.949463 & 0.581896 & 0.632419 & 2.540569 & \\
\hline
\end{tabular}

Sumber: Data Diolah (2018)

Berdasarkan tabel 8, di tahun 2014 perusahaan asuransi syariah Takaful Keluarga mendapatkan nilai Z-score 1,31. Tidak jauh berbeda dengan capaian ditahun 2012. Asuransi Takaful Keluarga masih berada pada grey area. Meskipun demikian, asuransi Takaful Keluarga mampu memperbaiki kinerjanya ditahun 2014. Indikasi perbaikan ini dapat dilihat pada variabel $\mathrm{X} 2$, yaitu pada rasio retained earning to total assets. Bila dibandingkan rasio retained earning to to total assets yang berhasil dicapai asuransi Takaful Keluarga di tahun 2013 sebesar -0,00831, pada tahun 2014 asuransi Takaful Keluarga berhasil memperbaiki rasio retained earning to total asset menjadi 0,00669.

Tabel 9. Perhitungan Z-Score 2015

\begin{tabular}{lccccc}
\hline \multicolumn{1}{c}{ TAHUN 2015 } & $\mathbf{X 1}$ & $\mathbf{X 2}$ & $\mathbf{X 3}$ & $\mathbf{X 4}$ & \multirow{2}{*}{ S Score } \\
\hline PANINDAI - ICHILIFE & $\mathbf{6 . 5 6}$ & $\mathbf{3 . 2 6}$ & $\mathbf{6 . 7 2}$ & $\mathbf{1 . 0 5}$ & \\
MEGA SYARIAH & 3.521511 & 1.237233 & 0.581222 & 1.454644 & 6.79461 \\
TAKAFUL KELUARGA & 1.000775 & 0.08188 & 0.128742 & 0.189022 & 1.40042 \\
PRUDENTIAL SYARIAH & 4.679052 & 2.319866 & 2.927835 & 5.032262 & 14.95901 \\
SINARMAS SYARIAH & 0.2207 & 1.393922 & 1.130117 & 1.23969 & 3.98443 \\
ADIRA SYARIAH & 2.285347 & 0.971578 & 0.453951 & 0.655087 & 4.365963 \\
\hline
\end{tabular}

Sumber: Data Diolah (2018)

Berdasarkan tabel 9, perusahaan asuransi Mega Syariah di tahun 2015 dapat mencapai Z-score sebesar 6,79. Pada tahun 2015, Mega Syariah berdasarkan nilai Z-score Z > 2,90 dikatergorikan perusahaan tidak bangkrut. Secara umum, kinerja asuransi Mega Syariah menunjukkan kinerja yang tetap stabil dari tahun 2011 sampai dengan 2015 dengan nilai Z-score 7,71; 5,40; 5,17 dan 6,90.

Capaian terendah Z-score di tahun 2015 diperoleh asuransi Takaful Keluarga $(1,40)$. Di tahun 2015 ini asuransi Takaful Keluarga tetap berada di grey area, perusahaan tidak dapat dikatakan bangkrut tetapi juga tidak dapat dikatakan sehat. Tidak jauh berbeda dengan capaian asuransi Takaful Keluarga di tahun 2013 dan 2014. Namun di tahun 
2015 ini kinerja keuangan perusahaan asuransi syariah Takaful Keluarga mengalami peningkatan terutama pada rasio retained earning to total asset. Pada tahun 2015, Takaful Keluarga mampu mebukukan laba ditahan sebesar Rp 26,737 miliar.

Tabel 10. Perhitungan Z-Score tahun 2016

\begin{tabular}{lcccrr}
\hline \multicolumn{1}{c}{ Tahun 2016 } & $\mathbf{X 1}$ & $\mathbf{X 2}$ & $\mathbf{X 3}$ & \multicolumn{1}{c}{$\mathbf{X 4}$} & \multirow{2}{*}{ Z Score } \\
& $\mathbf{6 . 5 6}$ & $\mathbf{3 . 2 6}$ & $\mathbf{6 . 7 2}$ & $\mathbf{1 . 0 5}$ & \\
\hline PANINDAI - ICHILIFE & 3.349945 & 1.139061 & 0.529643 & 11.8432 & 16.86185 \\
MEGA SYARIAH & 3.865512 & 1.431352 & 0.501287 & 1.944771 & 7.742922 \\
TAKAFUL KELUARGA & 0.761727 & 0.088421 & 0.085982 & 0.13794 & 1.07407 \\
PRUDENTIAL SYARIAH & 0.186584 & 0.092539 & 0.077362 & 5.987255 & 6.343739 \\
SINARMAS SYARIAH & 0.14048 & 1.757578 & 1.201589 & 1.895508 & 4.995155 \\
ADIRA SYARIAH & 0.635591 & 0.846096 & 0.407475 & 0.519682 & 2.408844 \\
\hline
\end{tabular}

Sumber: Data Diolah (2018)

Perusahaan asuransi Prudential Syariah di tahun 2016 ini memperoleh nilai Z-score sebesar 6,34. Dengan nilai Z > 2,90, maka perusahaan asuransi Prudential Syariah di tahun 2016 ini dikategorikan perusahaan tidak bangkrut. Namun hasil Z-score Prudential Syariah bila dibandingkan dengan tahun-tahun sebelumnya mengalami penurunan. Apabila dibandingkan dengan tahun 2015, Prudential Syariah mampu meraih Z-score sebesar 14,959. Penurunan nilai Z-score ditahun 2016 bila dibandingkan dengan tahun 2015 didominasi karena adanya perubahan 3 variabel rasio yang signifikan, yaitu rasio net working capital to total asset $(\mathrm{X} 1)$, rasio retained earning to total asset $(\mathrm{X} 2)$ dan rasio earning before tax to total aasset (X3).

Berbanding terbalik dengan yang terjadi pada perusahaan asuransi syariah Panindai - Ichilife, di tahun 2016 ini mampu mendapatkan nilai Z-score tertinggi $(16,86)$. Hal ini disebabkan meningkatnya rasio book value of euity to book value of debt, peningkatan ini didominasi karena penambahan nilai buku ekuitas, pada tahun 2015 nilai buku ekuitas yang dibukukan Rp 66,964 miliar namun di tahun 2016 meningkat menjadi Rp 79,169 miliar.

Tabel 11. Perhitungan Z-Score tahun 2017

\begin{tabular}{lccccc}
\hline \multicolumn{1}{c}{ TAHUN $\mathbf{2 0 1 7}$} & $\mathbf{X 1}$ & $\mathbf{X 2}$ & $\mathbf{X 3}$ & $\mathbf{X 4}$ & \multirow{2}{*}{ Score } \\
& $\mathbf{6 . 5 6}$ & $\mathbf{3 . 2 6}$ & $\mathbf{6 . 7 2}$ & $\mathbf{1 . 0 5}$ & \\
\hline PANINDAI - ICHILIFE & 2.352215 & 1.281223 & 0.517715 & 8.864456 & 13.01561 \\
MEGA SYARIAH & 5.236441 & 1.679129 & 0.34614 & 3.497621 & 10.75933 \\
TAKAFUL KELUARGA & 1.450821 & 0.042416 & 0.054498 & 0.119847 & 1.667583 \\
PRUDENTIAL SYARIAH & 5.381348 & 0.825845 & 0.637236 & 4.894626 & 11.73906 \\
SINARMAS SYARIAH & 3.028001 & 1.682141 & 0.703333 & 1.505778 & 6.919254 \\
ADIRA SYARIAH & 3.2828 & 0.774286 & 0.227229 & 0.416135 & 4.70045 \\
\hline
\end{tabular}

Sumber: Data Diolah 
Berdasarkan tabel 11, nilai Z-score ditahun 2017 secara umum perusahaan asuransi syariah berada pada $Z>2,90$; artinya secara umum peusahaan tidak dikatergorikan dalam kondisi bangkrut. Namun kinerja secara umum ini tidak dapat diikuti oleh asuransi syariah Takaful keluarga. Di tahun 2017 ini Takaful Keluarga mencapai nilai Z-score $1,67(1,23<Z<2,90)$, artinya perusahaan asuransi Takaful Keluarga berada pada grey area, perusahaan tersebut tidak dapat dikatakan pp. 123-136, ISSN p:2622-4755 bangkut tetapi juga tidak dapat dikatakan sehat.

Pada tahun 2017, ada beberapa perusahaan asuransi syariah yang mengalami kenaikan nilai Z-scorenya bila dibandingkan dengan tahun 2016. Mega Syariah, Takaful Keluarga, Prudential Syariah, Sinarmas Syariah dan Adira Syariah. Variabel yang mendominasi perubahan sehingga meningkatkan nilai Z-score kelima perusahaan asuransi syariah adalah rasio net working capital to total assets.

Pada tahun 2017 ini perusahaan asuransi syariah Panindai-Ichilife mengalami penurunan nilai Z-Score, bila dibandingkan tahun 2016. Hal ini dipengaruhi karena adanya penurunan rasio net working capital to total assets dan rasio book value of equity to book value of debt.

\section{KESIMPULAN}

Ditinjau dari rasio yang dihasilkan, pada tahun 2011 perusahaan asuransi Mega Syariah meghasilkan rasio sebesar 0.83, artinya setiap pemakaian Rp 1,- aktiva yang dimiliki perusahaan asuransi Mega Syariah mampu mengasilkan modal kerja bersih sebesar Rp 0,83. Di tahun 2012 Prudential Syariah mampu mendapatkan rasio net working capital to total asset 0,62.

Asuransi Takaful Keluarga dari tahun 2011 hingga 2013 menunjukkan nilai rasio retained earning to total aset negatif. Hasil rasio ini memungkinkan bernilai negatif dikarenakan nila dari laba ditahan yang dimiliki perusahaan asuransi syariah tersebut juga minus. Semakin tinggi rasio retained earning to total assets ini menunjukkan indikasi laba ditahan yang dihasilkan perusahaan asuransi syariah semakin tinggi. rasio retained earning to total asset tertinggi dimiliki oleh perusahaan asuransi Prudential Syariah sebesar 0,71 pada tahun 2015.

Pada tahun 2011-2015 rasio earning before tax to total assets tertinggi dimiliki oleh prudential syariah dengan rasio sebesar 0,86 ; 0,$72 ; 0,57 ; 0,54$ dan 044. Artinya di tahun 2011 setiap penggunaan Rp 1,- aktiva yang dimiliki Prudential Syariah mampu menghasilkan laba sebelum pajak sebesar Rp 0,86. Namun, pada tahun 2016 dan 2017 Prudential Syariah mengalami penurunan rasio, menjadi 0,01 dan 0,09. $\mathrm{Hal}$ ini dimungkinkan saja terjadi, dikarenakan adanya penurunan nilai laba sebelum pajak yang dibukukan.

Data rasio book value of equity to book value of debt perusahaan asuransi syariah dari tahun 2011 sampai dengan 2017. Perusahaan 
asuransi Takaful Keluarga dari tahun 2011 sampai dengan 2017 menghasilkan rasio terendah bila dibandingkan dengan perusahaan asuransi lainnya.

\section{REFERENSI}

Adnan M, Taufiq L. (2001). Analisis Ketepatan Prediksi Metode Altman Terhadap Terjadinya Likuidasi Pada Lembaga Keuangan Perbankan (Kasus Likuidasi Perbankan di Indonesia). J Akunt, 5(2).

Altman E. (1968). Financial Ratios, Discrriminant Analysis And The Prediction of Corporate Bangkruptcy. J Finance, 23(4):51-64.

DSN-MUI. (2001). Fatwa Dewan Syariah Nasional Majelis Ulama Indonesia No 21/DSN/MUI/X/2001 Tentang Penjelasan Asuransi Syariah.

Fatmawati Y. (2016). Analisis Potensi Kebangkrutan dengan Model Altman Z-Score pada Perusahan Asuransi Jiwa Syariah di Indonesia (Studi Kasus Perusahaan Asuransi Jiwa Syariah yang Terdaftar pada Asosiasi Asuransi Syariah Indonesia). Universitas Jember.

Mutawali. (2016). Analisis Kesehatan Keuangan dan Kebangkrutan Kepada Asuransi Bumiputera Syariah. J Illmu Prodi Manaj Univ Pamulung, 4 (1).

Otoritas Jasa Keuangan. (2018). Publikasi Otoritas Jasa Keuangan Tentang Laporan Statistik Bulanan Industri Keuangan Non-Bank (IKNB) Syariah. - (2015). Peraturan Otoritas Jasa Keuangan No 1/POJK.05/2015 Tentang Penerapan Manajemen Risiko Bagi Lembaga Jasa Keuangan Non-Bank.

Ramadhani A., Lukviarman N. (2009). Perbandingan Analisis Prediksi Kebankrutan Menggunakan Metode Altman Pertama, Altman Revisi dan Altman Modifikasi Dengan Ukuran dan Umur Perusahaan Sebagai Variabel Penjelas (Studi pada Perusahaan Manufaktur yang Terdaftar di Bursa Efek Indonesia). J Siasat Bisnis, 13 (1).

Redhika R, Mahalli K. (2014). Analisis Potensi dan Kendala Pengembangan Asuransi Syariah di Kota Medan. Jurnal Ekonomi dan Keuangan, 2 (5). 